\title{
Future Threats from Flooding
}

\author{
Alan Hisscott* \\ Chartered Meteorologist, MeteoVannin, Isle of Man
}

Submission: April 12, 2019; Published: April 25, 2019

*Corresponding author: Alan Hisscott, Chartered Meteorologist, MeteoVannin, Isle of Man

Keywords: Atmospheric; Oceanic; Climate change; Temperature; Salinity variations; Clean technology

\section{Opinion}

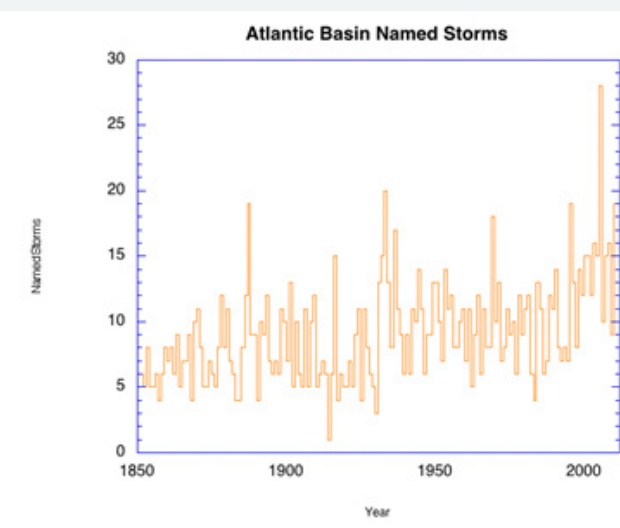

Figure 1: Source: http://www.aoml.noaa.gov/hrd/tcfaq/E11.htm

Are flooding events becoming more frequent or is it just better media coverage making us more aware of disasters around the world? Data from the US National Oceanic and Atmospheric Administration (NOAA) suggests that the number of significant storms over the Atlantic Basin has been increasing in recent years (Figure 1). Also, Figure 2, from the UN Intergovernmental Panel on Climate Change (IPCC), shows that the globally averaged surface temperature has also been increasing. If you look closely there is a remarkable correlation between these two graphs.

(a) Globally averaged combined land and ocean surface temperature anomaly

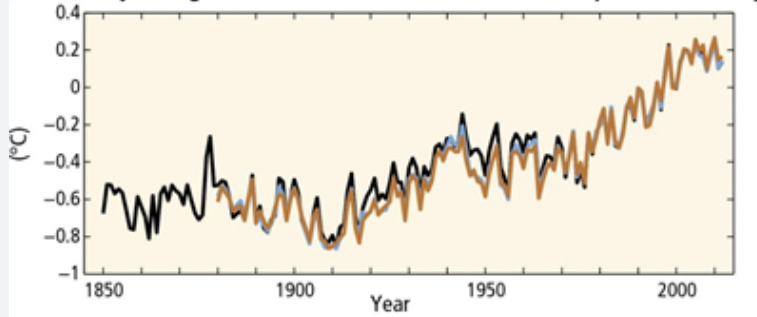

Figure 2: Source: IPCC, 2014: Climate Change 2014: Synthesis Report. Contribution of Working Groups I, II and III to the Fifth Assessment Report of the Intergovernmental Panel on Climate Change [Core Writing Team, Pachauri RK and Meyer LA (Eds.)] IPCC, Geneva, Switzerland, pp. 151.
Please note that I haven't mentioned 'climate change' or 'increasing C02'- these phrases still make an awful lot of people cringe and switch off, although the IPCC report does strongly suggest they are most likely related. The figures contain just pure scientific data - the historical facts as we know them. Global temperatures have been rising and so has storminess over the Atlantic Ocean, which often affects the British Isles. Storms reaching our coasts can bring surges in sea level, damaging waves, extreme wind and rainfall events, and the data shows these storms have been occurring more frequently. The IPCC Fifth Assessment Report also indicates that globally averaged sea level is increasing, due to thermal expansion from rising sea temperature and increased run-off water into the oceans from melting ice caps and glaciers.

The biggest overall threat from rising global temperatures is probably rising sea level, but not necessarily for everyone. Increasing the amount of water in the oceans is not like just filling a bath. Sea level varies significantly from place to place at any time because of tidal and wind-driven currents: the sea is never still. Also, there are some interesting local anomalies. For example, the sea level around Greenland is higher than might be expected due to the enormous mass of ice covering it, enough mass to gravitationally attract the surrounding sea towards the Greenland coast. Melting of the ice, reducing this mass, will reduce the gravitational attraction so the local sea level for hundreds of miles around the coast is expected to fall. However, the melt water will increase the overall volume of the oceans and contribute to rising sea levels in other places.

So, it's hardly surprising that sea level increases due to a warming climate will not be uniform and much research is going on to try to predict where it will increase most while in other places it will decrease. Also, tidal patterns and currents can depend on the water depth, especially in enclosed seas where tidal flows can resonate and amplify, so changing sea levels may also change local tidal regimes. With almost half of the world's population living within a few metres of sea level, and three-quarters of our major cities located on the coast, any changes will have 
enormous impact both economically and socially on many communities.

Also, the melt water from glaciers and ice caps is fresh water which may reduce the salinity of the oceans in certain places. This effect could be especially important for the North Atlantic, where the 'Gulf Stream' feeds the 'North Atlantic Drift' which brings a much milder climate to the British Isles than might be expected for our latitude. This current is largely driven by salinity variations so adding fresher water could possibly change the whole ocean circulation pattern, with consequent significant changes in weather patterns and climate, especially on seasonal temperatures and rainfall distribution.

Currently, much of the water expelled from glaciers is produced by pressure melting due to the weight of ice above, producing spectacular waterfalls in mountainous areas. The balance of reducing glacier mass from rising temperatures to the amount of melt water produced is not straightforward. Nature is full of very complicated non-linear feedback processes.

The only factor mitigating the rise in sea level due to melting glaciers and icecaps is the likely increase in water extraction from rivers as the global population continues to expand and developing countries become more industrialised. However, increased urbanisation can bring other problems, especially in view of likely overall seasonal changes in rainfall and in the frequency of extreme rainfall events.

Problems associated with rainfall flooding become more important as land is developed. Flooding of arable land is rarely a significant problem, but once land is developed flooding becomes a major financial and insurance risk, and sometimes a real danger. As towns and cities expand, the increased run off from concreted or tarmaced surfaces of water which would have previously been absorbed into the ground can cause problems for local drainage systems. Often overlooked in planning, developments in one place can cause other problems downstream. For example, many majestic historical bridges can be too small to accommodate new river flood volumes, a problem which can be difficult to circumvent due to heritage protection.

Are there any solutions? Flood risk mapping is already part of the planning process for most places. Any significant new developments should naturally include flood protection, but also remodelling of the whole river catchment to ensure problems are not transferred downstream, or even upstream.

Combined extreme-rainfall and tidal-flood risk models are being developed, often using 'joint probability' methods. However, the word 'storm' in 'storm surge' means there can often be significant rainfall associated with extreme tidal events. Also, severe winds can fell trees which can cause temporary river blockages which, when breached by increasing pressure of water, can cause devastating river surges.

Changing rainfall patterns can also increase the likelihood of landslides. Sequences of more prolonged drought periods interspersed with more extreme rainfall events can cause destabilisation of land which is geologically vulnerable to slip.

Are there any implications for 'clean technology'? Changing climate factors which lead to increased overall river flows in some places may make more hydro-electric schemes possible, particularly small turbine installations. Research into locating areas with rising sea level and strengthening tidal currents may bring new tidal-current and tidal-barrage opportunities. However, the timescale for significant changes in ocean circulation, and hence local tidal regimes, is likely far beyond the lifetime of any projects currently under consideration.

\begin{tabular}{l} 
Your next submission with Juniper Publishers \\
will reach you the below assets \\
- Quality Editorial service \\
- Swift Peer Review \\
- Reprints availability \\
- E-prints Service \\
- Manuscript Podcast for convenient understanding \\
- Global attainment for your research \\
- Manuscript accessibility in different formats \\
( Pdf, E-pub, Full Text, Audio) \\
- Unceasing customer service \\
Track the below URL for one-step submission \\
https://juniperpublishers.com/online-submission.php \\
\hline
\end{tabular}

